\title{
The Effectiveness of Micro-credit Programmes Focusing on Household Income, Expenditure and Savings: Evidence From Bangladesh
}

\author{
- Choudhury Haque Ariful, Das Atanu, Rahman Ashiqur
}

\begin{abstract}
This paper assesses the effectiveness of microfinance on household income, expenditure and savings. The survey examined those borrowers who had successfully completed at least three cycles of a loan. A household level survey $(\mathrm{N}=3000)$ was carried out to collect information about individuals receiving microcredit from one of the largest NGOs, ASA. The authors employed a multiple regression and discovered that the microcredit programme of ASA has a significant positive impact on household income, expenditures and savings. Moreover, the paper reveals that the level of education plays an important and statistically significant role in increasing the household income, expenditure and savings. Hence, the ASA microcredit programme has a positive impact on reducing poverty in Bangladesh and enhancing the competitiveness of deprived rural and urban households in improving their standard of living.
\end{abstract}

Keywords: MFIs, Collateral, Poverty, ASA, BR AC, Grameen Bank, Bangladesh

JEL Classification: C3, D02, G21, L31

\section{INTRODUCTION}

The growth of microfinance institutions (MFIs) has been so substantial in the twenty-first century so as to have become an incontrovertible aspect of the global economy, especially for thirdworld countries. The operational efficiency of the microfinance programme has achieved great success in alleviating poverty over the last couple of decades on a global scale (Hossain and Knight, 2008). For this reason, stakeholders believe that microfinance can play a pivotal role in improving the standard of living of the poor by creating income and employment opportunities (FEMIP, 2008; Khan and Rahman, 2016). Hossain (2012) contends that the impact of microfinance operations among the Bangladeshi rural inhabitants was remarkable, and he regards microfinance as a golden solution to poverty reduction. Being a developing country and having a poor infrastructure, Bangladesh's economy has been operating through an inefficient financial market (Sumi, 2010), through which it is almost impossible for the poor to get loans from financial institutions, which require sufficient collateral. In the rural areas of Bangladesh, some moneylenders are taking advantage of this constraint, offering loans to the poor at high interest rates with short repayment periods. Such acts are restraining the poor from investing in production and service-related businesses that might develop income-generating activities. In such cases, the poor exert great effort to quickly repay their loans, sometimes being forced to repay one loan with the proceeds from another. Alam (2012) notes that the inefficient infrastructure of Bangladesh creates a negative impression among banks and formal financial institutions, which 
then refrain from operating at the local level. Yunus (1999) stated that microfinance institutions give the poor access to the financial market. Poor people can get a loan from MFIs at an affordable interest rate without typing up their physical assets as collateral. He also emphasized that poverty could be eliminated by increased earnings, but that social poverty, such as ignorance and poor sanitation, cannot be removed without first creating social awareness. The prime task of the MFIs is to create awareness among the poor of the need to become more financially literate, to help borrowers lead self-sufficient lives with dignity. It is evident from various studies that microfinance has been successful in creating human capital by enabling the poor to become selfsufficient and live healthier lives.

In this study, the authors analyse the potential consequences of microfinance programmes on participants' income, expenditures, and savings. ASA has successfully operated its microfinance programme nationwide, with the highest number of branches among all the NGOs of Bangladesh (CDF, 2015). Moreover, ASA is the only NGO in Bangladesh among the top three market leaders (Grameen Bank and BRAC) that have experienced a 4\% increase in micro-finance loans (CDF, 2015). Due to its operational efficiency, the authors selected ASA MFI to conduct research on borrowers' lives, to assess whether the NGO helps only itself or benefits the country and its inhabitants as well.

\section{LITERATURE REVIEW}

Several indicators like food intake that is related to an increased income level, access to proper healthcare, land ownership, savings, sanitation, children's education, knowledge about family planning, and asset accumulation are taken into consideration to assess the overall socio-economic impact on the lives of the participants of different microfinance programmes.

Scholars have published many articles addressing the impact of microfinance on the livelihoods of the poor. Some studies have concluded that access to microfinance positively influences the poor, while others have expressed scepticism about the contribution of microfinance to the socio-economic development of the poor. For example, several recent studies claimed that microfinance has a significant positive impact on poverty reduction (see Biosca, Lenton, and Mosely, 2014; Koloma and Alia, 2014; Attanasio et al., 2015; Banerjee et al., 2015). On the other hand, some studies found no impact of microfinance on household income and expenditures (see Duvendack and Palmer-Jones, 2012; Augsberg et al., 2015, Angelucci, Karlan and Zinman, 2015). Hossain (2012) stated that economic development widens the path of social development. Wright (2000) emphasized that most of the NGOs of the world begin by teaching borrowers about health-related issues, providing small loans to install sanitary latrines, motivating them to receive primary education and consulting them on other socio-economic parameters to lead a healthier lifestyle. Khandker (2005), using World Bank data, discovered that both male and female participants of the BRAC NGO had been successful in increasing their level of consumption by $11 \%$ and $18 \%$, respectively. He also revealed that having access to small loans for at least three years positively influenced the borrowers. Pitt and Khandker (1998) reported that the microfinance programme contributed to building human capital, creating awareness regarding health issues and increasing consumption levels. Hossain (2008) found out that the clients of 
the BRAC microfinance programme had been successful at increasing their saving by five times and physical assets by 1.5 times compared to the poor who were not part of such a programme. Ahsanullah, Karim and Haq (2011) experienced 5-7\% growth in the income level among the participants whereas the non-participants did not experience any growth in their income. Chowdhury and Khandker (1996) stated that around $80 \%$ of the rural clients of BRAC and Grameen Bank microfinance programme had been able to meet their daily minimum calorie requirement. Chowdhury and Bhuiyan (2004) used seven factors to assess the overall impact of BRAC microfinance programme. The factors were family earning, birth controlling, standard environment, mortality rate, women empowerment, basic education and nutrition standard. Their survey result showed that the participants had been successful at reducing child mortality rate, increasing nutrition intake and increasing the percentage of school going children compared to the control group.

Newaz (2010) revealed that $27 \%$ of the households received the microcredit from one of the following three; ASA, BRAC and Grameen Bank, NGOs. His research showed that participants of the MFI programmes could manage three meals a day and the percentage increased by $10 \%$ whereas the non-participants remained same like before. It was evident from his report that the clients of MFIs invested their microloans in production and cultivation of crops, vegetables and fruits. Moreover, the participants invested their borrowed money in farming activities, such as fisheries and livestock that resulted in an increased income among the households. Newaz (2010) showed that the borrowers of different MFIs have been successful to ensure their food security, nutrition level and the level of income. Hossain (2012b) took a sample of 200 clients of BRAC NGO with minimum of 3 years of membership to assess the level of income after joining the micro finance programme. He stated that the borrowers have been successful at increasing their level of income by $250 \%$ compared to their non-membership period. He also found that the clients incurred around $89 \%$ of the total expenditure on food consumption, which was significantly higher compared to their prior position.

Hossain (2012 b) stated that the rate of school-going children in the rural areas of Bangladesh is alarming and the dropout rate is vulnerable as well. NGOs of Bangladesh are contributing positively to development of education system in the rural areas of Bangladesh. BRAC's non-formal education (NFE) played a significant role by creating awareness among its clients about the importance of education in human lives. BRAC is providing education throughout the nation with its thirty eight thousand informal primary schools (BRAC at a glance, 2011). Ahshanullah, Karim and Haq (2011) with the reference of BRAC's research division stated that the child age group between 11 and 14 of the BRAC participants experienced $12 \%$ increase in educational competency compared to their non-participant condition. Hossain (2012 b) argued that the boys and girls of the microfinance borrowers' get more basic education compared with the boys and girls of the non-borrower households. He also revealed that approximately $92 \%$ of the ASA microfinance participants agreed about the increased literacy rate of their children. Newaz (2010) found that participants with a long-term membership with the MFIs experienced an improved education status of their children compared to the short-term participants. From the above-mentioned evidences, it is clear that MFIs are playing a significant part to promote education among the poor and deprived rural children and it is clear that a longer membership 
with the MFIs facilitates borrowers' children to receive more education than short-term MFIs' borrowers' children.

Ahshanullah, Karim and Haq (2011) showed that a longer-term of membership with BRAC resulted in an increased asset accumulation within the borrowers' families. ASA annual report (2009) showed that the microfinance borrowers' families experienced an increase in household assets. Around $58 \%$ of the total respondents experienced an increase in land, $63 \%$ experienced increase in domestic animal and 49\% experienced an increased amount of ornaments. Hossain (2012b) showed that only $9 \%$ of his total sample had tube-wells before joining the programme whereas the percentage soared to $28 \%$ after joining the microfinance programme. It can be said that the microfinance programmes facilitate borrowers to increase their asset base.

Living standard of people can be measured by considering their housing condition. Houses of the rural areas are made by bamboo, thatch, tin and clay. Dwellers of such houses perpetually remain in the fear of natural disasters, such as cyclone, flood and unnatural turbulence like theft and robbery. As the houses of the poor people are not so durable, they suffer from rainfall because majority of the homes generally have many holes whereas the houses of urban areas are built with cements, iron and bricks (Khondkar, 1999). Hossain (2012b) showed that before joining the microfinance programmes, $87 \%$ of respondents of his study used to live in houses made by thatch and clay which were risky to live in. After joining microfinance programmes, the percentage of respondents living in the risky houses decreased by $36 \%$. The houses having built with a tin roof and clay walls were experienced by $13 \%$ of respondents, and it rose by $162 \%$ after joining the microfinance programme. He also found that $11 \%$ of the total samples were able to build tin made houses after being the part of microfinance programme whereas no participants had tin made houses before joining such programme.

Hossain (2012 a) stated that participants of the BRAC microfinance programme had been able to secure improved sanitary conditions after joining the microfinance programme and the percentage improved from 39 to $100 \%$. It was also evident from his survey that members of the BRAC microfinance programme have been enabled to install their own tube-well after being the part of such programme and the percentage increased by $19 \%$ compared to their non-membership period. He added that the percentage of the participants' children education significantly changed after joining the BRAC microfinance programme. The result showed that $93 \%$ of the total sample's children attend school after joining such programme whereas the percentage was only $52 \%$ before. BRAC's health awareness programme contributed significantly among the members. Before joining the BRAC programme, only $58 \%$ and $27 \%$ of the total sample had knowledge of hygiene and nutrition respectively whereas the percentage turned into $83 \%$ and $50 \%$ after joining such programme.

The impact analysis report of ASA (2013) showed that around $97 \%$ of the total sample had been successful at increasing their monthly income after joining the microfinance programme. Moreover, food intake improved significantly among the members after joining the programme. The increased income enabled them to take quality food that was not available for them before joining the microfinance programme. Rahman and Khan (2013) also found out that the microcredit programme of ASA has a positive impact on poverty reduction in Bangladesh. By considering all the facts and limitations, the authors of this report tried to apply appropriate techniques to assess 
the real scenario that might help the readers get an honest scenario of the ASA microfinance programme's efficiency.

\section{METHODOLOGY}

\subsection{Data and questionnaire design}

This study administers a field survey in 20 districts in Bangladesh, during the period from April 2015 to November 2015, using a structured questionnaire. The survey only aimed at interviewing those borrowers who had successfully completed at least three cycles of loan.

The questionnaire was designed by the ASA Research Section in order to conduct a survey for determining the impact of microfinance.

\subsection{Data collection}

The data was collected through face-to-face interviews over the period from April 2015 to November 2015. The survey was carried out by the ASA Research Section. The survey aimed at collecting the respondents' demographics, household income and expenditure and credit- related information through a structured questionnaire. This study elicited information about the age, gender composition and level of education of the respondents' family members. The research section provided training on technical terms and coding of the questionnaires and ways to carry out interviews and complete the information correctly. The objectives of the study were also clearly explained to them. The data were collected from 20 districts (out of 64 districts), covering eight divisions (highest administrative units) of the country.

A three stage sampling design was applied to collect the data. In the first stage, 20 districts were selected based on the poverty indicators, such as the literacy rate and poverty head count ratio of the districts.

In the second stage, 60 rural branches and 40 urban branches were chosen randomly. Hence, in total of 100 branches were chosen for the survey from 20 districts. The staff members of ASA Research Section visited all 100 selected branches and provided training to the loan officers and the branch managers as they were directly involved in conducting face-to-face interviews. The main purpose of the visit was to give hands on training on ways to carry out face-to-face interviews and to create a friendly environment with the interviewees and thus, get the information to complete the questionnaires. The survey team carried out 3 to 4 interviews at each selected branch in order to show them properly and thus, improving the quality of the data. The field level management staff members (Regional Managers/District Managers) were involved along with the branch managers for monitoring purposes and follow-up of the survey.

In the final stage, respondents, both male and female borrowers who had completed at least three cycles of loan were randomly selected. After completion of the survey in each branch, the concerned branch manager was asked to send the filled-up questionnaires back to the head office. Finally, the research section processed the data for the analysis. 


\subsection{Empirical model}

In order to empirically estimate the impact of ASA's microfinance programme on the financial indicators, this study uses the length of ASA membership to capture the impact of the ASA's microfinance programme. This study also uses a number of independent variables and these are: head of household's age, head of household's age square, ASA membership, female (borrower) education, head of household's education and household size. Our empirical models to be estimated are as follows:

$\log ($ Income $)=\beta 0+\beta 1 \mathrm{HH}$ Age $+\beta 2$ Age $(\mathrm{HH})$ Square $+\beta 3$ Length of ASA Membership $+\beta 4$ Female Education $+\beta 5$ HH Education $+\beta 6$ HH Size $+\mu \ldots \ldots \ldots \ldots . .($ Model 1)

$\log ($ Expenditure $)=\beta 0+\beta 1 \mathrm{HH}$ Age $+\beta 2$ Age $(\mathrm{HH})$ Square $+\beta 3$ Length of ASA Membership $+\beta 4$ Female Education $+\beta 5$ HH Education $+\beta 6$ HH Size $+\mu$ (Model 2)

$\log ($ Savings $)=\beta 0+\beta 1 \mathrm{HH}$ Age $+\beta 2$ Age $(\mathrm{HH})$ Square $+\beta 3$ Length of ASA Membership

$+\beta 4$ Female Education $+\beta 5$ HH Education $+\beta 6$ HH Size $+\mu \ldots \ldots \ldots \ldots \ldots$ (Model 3)

In the above-mentioned models, $\beta 0$ is the constant and $\beta 1, \beta 2, \beta 3, \beta 4, \beta 5, \beta 6$, are the coefficients and a usual error term is $\mu$.

\section{EMPIRICAL RESULTS}

The following table presents the results obtained from the regression models of household income, expenditure and savings.

Tab. 1 - Results of the Regression Models on the Financial Indicators. Source: Authors own estimation

\begin{tabular}{|c|c|c|c|}
\hline & (Model 1) & (Model 2) & (Model 3) \\
\hline Ind. Variables & $\log$ (Income) & $\log ($ Expenditure $)$ & $\log$ (Savings) \\
\hline \multirow{2}{*}{ HH Age } & -0.00582 & -0.00320 & $-0.0612 * * *$ \\
\hline & $(0.00504)$ & $(0.00472)$ & $(0.0132)$ \\
\hline \multirow{2}{*}{ HH Age Square } & $9.71 \mathrm{e}-05^{*}$ & $4.88 \mathrm{e}-05$ & $0.000645^{* * *}$ \\
\hline & $(5.47 \mathrm{e}-05)$ & $(5.14 \mathrm{e}-05)$ & $(0.000143)$ \\
\hline \multirow{2}{*}{ ASA Membership } & $0.000961 * * *$ & $0.000941 * * *$ & $0.00125^{* *}$ \\
\hline & $(0.000238)$ & $(0.000224)$ & $(0.000635)$ \\
\hline \multirow{2}{*}{ Female Education } & 0.0159 *** & $0.0146^{* * *}$ & $0.0441 * * *$ \\
\hline & $(0.00367)$ & $(0.00345)$ & $(0.00969)$ \\
\hline \multirow{2}{*}{ HH Education } & $0.0200^{* * *}$ & $0.0200^{* * *}$ & $0.0289 * * *$ \\
\hline & $(0.00315)$ & $(0.00295)$ & $(0.00830)$ \\
\hline \multirow{2}{*}{ Household Size } & $0.0941 * * *$ & $0.104 * * *$ & $0.0455^{* *}$ \\
\hline & $(0.00676)$ & $(0.00634)$ & $(0.0179)$ \\
\hline \multirow{2}{*}{ Constant } & $9.263 * * *$ & $8.891^{* * *}$ & $9.739 * * *$ \\
\hline & $(0.120)$ & $(0.112)$ & $(0.312)$ \\
\hline
\end{tabular}




\begin{tabular}{|l|c|c|c|}
\hline Observations & 2,871 & 2,869 & 2,742 \\
\hline R-squared & 0.111 & 0.131 & 0.045 \\
\hline
\end{tabular}

$\mathrm{HH}=$ Head of Household; Standard errors in the parentheses. $* * * \mathrm{p}<0.01, * * \mathrm{p}<0.05, * \mathrm{p}<0.1$

\subsection{The impact on household income (Model 1)}

The head of household's age is found to have a negative impact on the household income, but this is not statistically significant. However, the head of household's age square is found to have a positive and statistically significant impact, indicating that as the head of household gets older, the effect of age on the household income increases. This could be due to the fact that when the head of household gets older, the contributions to the household income from other family members, such as a son or daughter, are more likely to be increased.

Participation in ASA is added to capture the impact of the microfinance programme on household income. As expected, the length of participation is found to have a positive impact on household income, and this is statistically significant. This study revealed that each year associated with ASA added 1.5 percent to the household income. This indicates that the borrowers who remained successfully in the programme for more than three years managed to increase their household income.

In Model 1, female (borrower) education and the head of household's education are found to have a positive impact on household income, and these are statistically significant. With regard to the level of education, both the female (borrower) education and the head of household's education increase household income. Similarly, this study found that the household's size is positive and statistically significant, indicating that the household's size increases the total income.

\subsection{The impact on the household expenditures (Model 2)}

In model 2, the head of household's age and the head of household's age square are not statistically significant. However, the length of ASA participation is found to have a positive relevance and is statistically significant. This indicates that with each year of participation with ASA, household expenditures increase by 1.13 percent. With regard to the level of education, both the female (borrowers) education and the head of household's education are found to be positive and statistically significant. As expected, the results indicate that the level of education increases the household expenditures. Moreover, the household's size is found to be positive and statistically significant, indicating that the household's size increases the total household expenditures.

\subsection{The impact on the household savings (Model 3)}

In model 3, the head of household's age is found to have a negative impact on the household savings, and it is statistically significant. Moreover, the head of household's age square is found to have a positive impact on the household savings, and it is also statistically significant. The results indicate that as the head of household gets older, the household savings increase. This could be due to the fact that the elderly need to consider the costs associated with their future medical treatment if they need and tend to rely on their own savings as they get older. 
As expected, the length of ASA's participation is found to have a positive and statistically significant impact on household savings, indicating that the borrowers increase their household savings by 1.25 percent per year.

Similar to the results of study on household income and expenditures, this study found out that the level of female (borrower) education and the head of household's education are having a statistically significant positive impact on the household savings. Surprisingly, household size increases the savings, and this is also statistically significant.

\section{DISCUSSIONS}

As explained, microfinance is a small amount of credit that is designed for the poor of Bangladesh. Microfinance institutions do not require any collateral to secure the loan. Therefore, this collateral-free credit has become popular nationwide, in particular, among the poor. Although there is a debate over the impact of microfinance on poverty reduction, this study confirmed that the microfinance programme of ASA has a positive impact on increasing its borrowers' household income, expenditures and savings. In particular, the empirical results of this study reveal that the household income, expenditures and savings increased by 1.15 percent, 1.13 percent, and 1.25 percent respectively per year. The findings of this study are similar to the studies that found a positive impact of microfinance on household income and expenditures (Hossain, 2012b; Rahman and Khan, 2013; Koloma and Alia, 2014; Attanasio et al., 2015; and Banerjee et al., 2015). It is worth noting that microfinancing is being provided to the poor who are unable to provide collateral and/or do not have access to commercial banks. However, ASA's microfinance programme focuses on the disadvantaged and provides credit to those borrowers who suffer from a cash crisis regarding their existing businesses as well as capital for starting-up their new businesses. The loan officers of ASA ensure that their borrowers take care of their business projects and make appropriate use of the loan given to them. They also provide various income generation trainings to their borrowers, such as gardening, sewing, and agriculture. These efforts could have a significant impact on increasing income and therefore expenditures. ASA also encourages their borrowers to keep saving money with their institution because the income of the poor is often inconsistent throughout a year. Hence, poor people can use their savings whenever they experience a cash crisis. Therefore, ASA encourages its borrowers to save money as much as they can every week for their future betterment.

\section{CONCLUSION}

This study investigated the impact of microfinance on household income, expenditures, and savings. It is evident from our study that the income, expenditures and savings of ASA clients increased significantly with the use of microfinancing for their intended purpose. Hence, this study concluded that the microcredit programme of ASA has a positive impact on poverty reduction, and that it helps both rural and urban needy households improve their standards of living due to their increased income, expenditures and savings. To conclude, it could be argued that microfinance institutions may gain a competitive advantage if the institutions provide not only microfinancing but also other various services, such as education, skill-based programmes and training sessions that are needed to alleviate poverty. 


\section{Acknowledgement}

The authors are thankful to the Internal Grant Agency of FaME TBU No. IGA/FaME/2017/010: Financial Constraints on Economic Activities, for financial support to carry out this research.

\section{References}

1. Ahsan, A. H. M. K. (2005). The role of NGOs health, family planning and education Programme in poverty reduction in Bangladesh: A study on BRAC. Pakistan Journal of Social Science, 3(8), 1075-1081, DOI: doi:10.5539/ibr.v5n4p112.

2. Ahshanullah, M., Karim, R. and Haq, E. (2011). Reaching the poor: Microcredit Experience in Bangladesh. AS A University Review, 5(2), 11-33.

3. ASA (2013). Impact Assessment of ASA Microfinance Programme. Retrieved from: http://www.asa.org.bd/impact-assessment (Accessed on 16th October 2016).

4. Alam, S. (2012). The effect of gender- based returns to the borrowing on intra-households resource allocation in rural Bangladesh. World Development , 40(6), 1164-1180.

5. Angelucci, M., Karlan, D. and Zinman, J. (2015). Microcredit Impacts: The evidence from a Randomized Microcredit Program Placement Experiment by Compartamos Banco. American Economic Journal: Applied Economics, 7(1), 151-182.

6. Attanasio, O., Augsburg, B., De Haas, R., Fitzsimons, E. and Harmgart, H. (2015). The Impacts of Microfinance: Evidence from Joint-Liability Lending in Mongolia. American Economic Journal: Applied Economics, 7(1), 90-122.

7. Augsburg, B., De Hass, R., Harmgart, H. and Meghir, C. (2015). The Impacts of Microcredit: Evidence from Bosnia and Herzegovina. American Economic Journal: Applied Economics, 7(1), 183-203.

8. ASA.(2009). ASA Annual Report 2009, Dhaka: ASA.

9. Banerjee, A., Duflo, E., Gelnnerster, R. and Kinnan, C. (2015). The Miracle of Microfinance? The evidence from a Randomized Evaluation. American Economic Review: Applied Economics, 7(1), 22-53.

10. Biosca, O., Lenton, P. and Mosely, P. (2014). Where is the 'Plus' in 'Credit-Plus'. The Case of Chiapas, Mexico. The Journal of Development Studies, 50(12), 1700-1716.

11. BRAC. (2011). BRAC at a Glance. Available at: http://www.brac.net/content/stayinformed-brac-glance\#Education\%20Programmeme (Accessed on 18/10/2016).

12. CDF. (2015). Bangladesh Microfinance Statistics. Credit and Development Forum, Dhaka.

13. Chowdhury, A.M.R, and Bhuiyan, A. (2004). The Wider Impact of BRAC poverty alleviation Programme in Bangladesh. Journal of International Development, 16(3), 369-386.

14. Chowdhury, O.H., and Khandaker, S.R. (1996). Do the Targeted Credit Programmes improve the Nutritional Status of The poor? BIDS Working paper No. 57.

15. Duvendack, M. and Palmer-Jones, R. (2012). High Noon for Microfinance Impact Evaluations: Re-investigating the Evidence from Bangladesh, Journal of Development Studies, 2012, 1-17, iFirst article. 
16. FEMIP, (2008). A review of the economic and social impact of microfinance with analysis of options for the Mediterranean Region, Final Report, European Investment bank. Available at: http://www.microfinancegateway.org/gm/documnet-1.9.43227/21.pdf (Accessed on 11/10/2016).

17. Hossain, F. and Knight, T. (2008). Financing the poor: Can microfinance do the difference? The empirical evidence from Bangladesh. BWPI working paper 38. Available at: http://www.bwpi.manchester.ac.uk/resources/Workin-papers/bwpi-wp-3808.pdf, (Accessed on 11/10/2016).

18. Hossain, M.K. (2008). Community Development and Livelihood Security: BRAC's Experience in Bangladesh and Afghanistan. The paper presented to The Tokyo Peace builders' Symposium 2008, UN House, Tokyo, March 24-25. Available at: http://www.mofa.go.jp/ policy/un/pko/symposium0803/hossain.pdf, DOI: doi:10.5539/ibr.v5n4p112.

19. Hossain, M.K. (2012 a). The Assessment of Social Impact Of Microfinance Operations: A Study on BRAC, Interdisciplinary Journal of Research in Business, 2(3), DOI: doi:10.5539/ ibr.v5n4p112.

20. Hossain, M. K. (2012 b). Measuring the Impact of BRAC Microfinance Operations: A case Study of a village. International Business Research, 5(4), 112- 123.DOI: doi:10.5539/ibr. v5n4p112.

21. Khandker, S.R. (2005). Microcredit and poverty: Evidence sing panel data from Bangladesh. World Bank Economic Review, 19(2), 263-287 DOI: https://doi.org/10.1093/wber/ lhi008.

22. Khondkar, M. (1999). Conceptualization of poverty: The Bangladeshi rural women's experience. Dhaka University Journal of Business Studies, 20(2), 109-136.

23. Koloma, Y. and Alia, H. (2014) Gendered Impact of Microcredit in Mali: An Evaluation by Propensity Score Matching. Strategic Change, 23, 517-530.

24. Newaz, S. (2010). Microfinance and poverty Reduction: The evidence from a Village Study In Bangladesh, Journal of Asian and African Studies, 45(6), 670-683. DOI: 10.1177/0021909610 383812.

25. Pitt, M. (1999). Reply to Jonathan Morduch's Does Microfinance really help the poor: new evidence from flagship Programmes in Bangladesh, Province, RI: Department of Economics, Brown University. Available at http://www.microfinancegateway.org/gm/ document-1.9.24728/36058_file_01.pdf (Accessed on 20th August 2016).

26. Rahman, M.T. and Khan, H.T.A. (2013). The Effectiveness of Microcredit Programme in Bangladesh. Local Economy, 28(1), 85-89.

27. Khan, H.T.A., and Rahman, M. T. (2016). Women's Participations in Economic and NGO Activities in Bangladesh: An Empirical Study on the Bangladesh Demography and Health Survey. International Journal of Sociology and Social Policy, 36(7/8), 491-515.

28. Sumi, S.M. (2010). Beacon of Hope. Dhaka: ASA.

29. Wright, G.A.N. (2000). Microfinance Systems: Designing Quality Financial Services for the Poor. London \& New York: Zed Books, and Dhaka: University press Ltd. 
30. Yunus, M.(1999). Banker to the poor: micro lending and the battle against world poverty. New York: Public Affairs.

\section{Contact information:}

Md. Ariful Haque Choudhury

Deputy Director

ASA Bangladesh

Address: ASA Tower, 23/3 Bir Uttam Sharak.

Shyamoli, Dhaka-1207, Bangladesh

E-mail:arif.tanzil@gmail.com

Atanu Das

Research Officer, AS A Bangladesh

Address: AS A Tower, 23/3 Bir Uttam Sharak.

Shyamoli, Dhaka-1207, Bangladesh

E-mail:atdas@asabd.org

\section{Ashiqur Rabman}

Doctoral Candidate in Finance

Tomas Bata University in Zlín

Department of Enterprise Economics

Faculty of Management and Economics

Address: Mostni 5139, 76001 Zlin

Czech Republic

E-mail:rabman@fame.utb.cz. 